\title{
SERUM C-C MOTIF LIGAND 11/EOTAXIN-1 MAY SERVE AS A CANDIDATE BIOMARKER FOR POSTMENOPAUSAL OSTEOPOROSIS
}

\author{
SERUMSKI C-C MOTIV LIGAND 11/EOTAKSIN-1 MOŽE POSLUŽITI KAO KANDIDAT \\ ZA BIOMARKER OSTEOPOROZE KOD ŽENA U MENOPAUZI
}

\author{
Wen Wang 1, Ci-You Huang1, Zhuo-Ping Wang ${ }^{1}$, Shan-Shan Xu1, Tie-Yong Qian 1, \\ Yi-Ding Chen ${ }^{1}$, Wei-Guo Wu ${ }^{1}$ \\ ${ }^{1}$ Department of Endocrinology, The Affiliated Wuxi No. 2 \\ People's Hospital of Nanjing Medical University, Wuxi, China, 214002
}

\section{Summary}

Background: The chemokine C-C motif ligand 11, also known as eotaxin-1, has been identified as a novel mediator of inflammatory bone resorption. However, little is known regarding a potential role for CCL11/Eotaxin-1 in postmenopausal osteoporosis.

Objective: The scope of this study was to explore the relationship between serum CCL11/Eotaxin-1 concentrations and disease progression of postmenopausal females with osteoporosis.

Methods: A total of 83 postmenopausal women diagnosed with osteoporosis were enrolled. Meanwhile, 82 postmenopausal women with normal bone mineral density (BMD) and 85 healthy controls inner child-bearing age were enrolled as control. The Dual-energy X-ray absorptiometry was used to examine the BMDs at the femoral neck, lumbar spine 1-4 and total hip of all participants. Serum CCL11/Eotaxin-1 levels were examined by enzyme-linked immunosorbent assay. We also included inflammation marker interleukin-6 (IL-6) as well as a serum marker of bone resorption C-telopeptide cross-linked collagen type 1 (CTX-1). The Visual Analogue Scale (VAS) and Oswestry Disability Index (ODI) were recorded to evaluate the clinical severity in POMP females.

Results: Serum CCL11/Eotaxin-1 levels were significantly elevated in postmenopausal osteoporotic patients PMOP patients compared with PMNOP and healthy controls. We observed a significant negative correlation of serum CCL11/Eotaxin-1 levels with lumbar spine, femoral neck

\section{Kratak sadržaj}

Uvod: Hemokin (C-C motiv) ligand 11, poznat i pod nazivom eotaksin-1, identifikovan je kao novi posrednik zapaljenske resorpcije kostiju. Međutim, malo se zna o potencijalnoj ulozi CCL11/Eotaksin-1 u postmenopauzalnoj osteoporozi.

Cilj: Cilj ove studije bio je istraživanje odnosa između serumskih koncentracija CCL11/Eotaksin-1 i progresije bolesti osteoporoze kod žena u postmenopauzi.

Metode: $U$ istraživanju su ukupno učestvovale 83 žene sa dijagnozom osteoporoze u postmenopauzi. $U$ međuvremenu su u studiju uključene 82 žene u postmenopauzi sa normalnom mineralnom gustinom kostiju (BMD) i 85 zdravih žena sposobnih za rađanje kao kontrolna grupa. Za ispitivanje BMD-a na vratu femura, lumbalne kičme 1-4 i celog kuka svih učesnica korišćena je dvoenergentska rentgenska apsorpciometrija. Serumske koncentracije CCL11/Eotakisn-1 su ispitane pomoću enzimski vezanih imunosorbentnih testova. Takođe smo uključili i inflamatorni marker interleukin-6 (IL-6), kao i serumski marker koštane resorpcije C-telopeptidnog ukrštenog kolagena tipa 1 (CTKS-1). Zabeleženi su rezultati na Vizuelnoanalognoj skali (VAS) kao i Oswestry indeks invalidnosti (ODI) za procenu ozbiljnosti kliničke slike kod žena sa postmenopauzalnom osteoporozom.

Rezultati: Serumski CCL11/Eotaksin-1 nivoi su bili značajno povišeni kod pacijenata sa postmenopauzalnom osteoporozom (PMOP) u poređenju sa PMNOP i zdravom kontrolnom grupom. Posmatrali smo značajnu negativnu korelaciju serumskih nivoa CCL11/Eotaksin-1 sa BMD-om

\section{Address for correspondence:}

Zhuo-Ping Wang

Department of Endocrinology,

The Affiliated Wuxi No. 2 People's Hospital of Nanjing Medical University, Zhong Shan Road No.68, Liang Xi

District, Wuxi, Jiang-Su Province, China, 214002

e-mail: xueyin801215@163.com

Wen Wang and Ci-You Huang contributed equally to this work 
and total hip BMD. Furthermore, serum CCL11/ Eotaxin-1 concentrations were also positively related to the VAS and ODI scores. Last, serum CCL11/ Eotaxin-1 concentrations were positively associated with IL- 6 and CTX-1 levels. These correlations remain significant after adjusting for age and BMI. Multivariate linear regression analysis demonstrated that CCL11/Eotaxin-1 could serve as an independent marker.

Conclusions: Serum CCL 11/Eotaxin-1 may serve as a candidate biomarker for postmenopausal osteoporosis. Therapeutics targeting CCL11/Eotaxin-1 and its related signalling way to prevent and slow progression of PMOP deserve further study.

Keywords: chemokine C-C motif chemokine 11, eotaxin1, postmenopausal osteoporosis, disease severity

\section{Introduction}

Osteoporosis (OP) is characterised by low bone mass and micro-architectural deterioration of bone tissue, with a consequent increase in bone fragility and susceptibility to fracture (1). The excessive bone loss in OP occurs as a result of an increase in the rate of bone remodelling and a negative imbalance between bone formation and resorption (2). Although the causes of OP remain uncovered, ageing and estrogen deficiency have been regarded as two key factors in the pathogenesis of OP (3). According to the statistics, approximately $21 \%$ of women aged 50 84 years are classified as having OP (4). With regard to the postmenopausal osteoporosis, bone loss accelerates during the late stage of menopausal transition and continues for the next two decades at a rapid pace (5). Although various drugs have been developed, there are currently still no established methods for effective prevention of bone destruction in OP.

So far, OP is chiefly diagnosed on the basis of the detected reduced BMD volume by DXA and symptoms of pain as well as impaired function ability (6). However, obvious reduction of BMD and radiological alternations including the presence of reduction of trabecular bone or fracture are almost signs of medium-late stage osteoporosis (7). Hence, to seek more effective, early and reliable screening method is an urgent task.

Recently, biochemical markers of bone turnover are widely used to reflect bone metabolism and monitor treatment response. Biomarkers have been identified to be more useful than serial BMD measurements in that they are non-invasive, relatively cheap compared with DXA and can detect changes in bone turnover rates earlier (8). Therefore, discovering novel and reliable biomarkers are valuable methods for developing new drugs to prevent or delay OP progression

Chemokines are a large family of small cytokines and generally have low molecular weight lumbalne kičme, vratom femura i celog kuka. Pored toga, serumska koncentracija CCL11/Eotaksin-1 takođe je pozitivno povezana sa rezultatima VAS i ODI. Poslednje, serumska koncentracija CCL11/ Eotaksin-1 je bila pozitivno povezana sa nivoima IL-6 i CTKS-1. Ove korelacije i dalje ostaju značajne nakon usklađivanja sa godinama $\mathrm{i}$ BMI. Multivarijantna linearna regresiona analiza pokazala je da CCL11/Eotaksin-1 može poslužiti kao nezavisni marker.

Zaključak: Serumski CCL 11/Eotaksin-1 može poslužiti kao kandidat za biomarker za postmenopauzalna osteoporozu. Terapija koja targetira CCL11/Eotaksin-1 i njegov signalni put u cilju sprečavanja i usporavanja progresije PMOP-a zaslužuje dalja istraživanja.

Ključne reči: Hemokin C-C motiv hemokin 11, Eotaksin1 , postmenopauzalna osteoporoza, ozbiljnost bolesti

ranging from 7 to $15 \mathrm{kDa}(9)$, and they are described as chemoattractant cytokines synthesised at sites of inflammation and are the regulatory proteins for leucocyte recruitment and trafficking (10). Chemokines are divided into $\mathrm{C}, \mathrm{CC}, \mathrm{CXC}$ and $\mathrm{CX} 3 \mathrm{C}$ subfamilies on the basis of number and spacing of cysteine residues within their $\mathrm{N}$-terminal regions (11). Recently, chemokines have been identified to be involved in osteoclastogenesis.

The chemokine CCL11 (C-C motif ligand 11) or Eotaxin-1, is a member of the CC chemokine family and was originally found to recruit eosinophils to sites of inflammation, particularly in allergic diseases and asthma (12). It is produced by lymphocytes, eosinophils and monocytes/macrophages, and interacts with C-C chemokine receptor 3 (CCR3) (13). This receptor is expressed by T-lymphocytes, eosinophils, basophils, dendritic cells, and a recent study has also suggested the expression of CCR3 on osteoclasts (14). New findings have shown that CCL11 plays an important role in OCs migration. In a recent study, CCL11 was coupled with its receptor CCR3 in OCs under conditions of inflammatory bone resorption in vivo (15). It also demonstrates that RANKL stimulated CCR3 expression in OCs in vitro and that addition of CCL11 results in increased migration of OC precursors and enhanced osteoclastic bone resorption (15). Another earlier study has shown that elevated serum levels of CCL11 were related to less radiographic progression in early rheumatoid arthritis (RA) patients, indicating CCL11 is involved in the bone erosion or damage process (16).

The studies mentioned above suggest that CCL11/Eotaxin-1 may play a vital role in the development of OP. But there were no studies before investigating the correlation between CCL11/Eotaxin1 levels and progression of OP. The scope of this study was designed to examine whether CCL11/Eotaxin-1 levels are elevated in PMOP as well as the correlation of the serum CCL11/Eotaxin-1 concentration with disease severity in PMOP females. 


\section{Materials and Methods}

\section{Study patients}

From April 2017 to August 2018, a total of 83 postmenopausal women diagnosed with osteoporosis were enrolled in our study. Menopause was defined as the absence of menstruation for at least 12 months and estrogen lower than $50 \mathrm{pg} / \mathrm{mL}$ as well as FSH levels higher than $40 \mathrm{IU} / \mathrm{L}$. Exclusion criteria were a body mass index (BMI) below 19 or over $27 \mathrm{~kg} / \mathrm{m}^{2}$, bilateral oophorectomy, undiagnosed vaginal bleeding, endometrial hyperplasia, inflammatory disease, or any condition likely to require corticosteroid treatment, bone diseases, liver enzyme abnormalities, a history of cancer. Patients were also excluded if they had used estrogens within the last 6 months, or had calcitonin or vitamin D treatment within the last 2 months, and drugs known to interfere with calcium metabolism. Meanwhile, 82 age-matched postmenopausal non-osteoporotic females and 85 healthy controls inner child-bearing age receiving routine body check in our hospital during the same period were recruited as controls. The ethics committee of the Affiliated Wuxi No.2 People's Hospital of Nanjing Medical University approved this study and written informed consent was obtained from all the subjects before participation. This study also complied with the World Medical Association Declaration of Helsinki's Ethical Principles for Medical Research Involving Human Subjects.

\section{Laboratory Examination}

A venous blood sample of $10 \mathrm{~mL}$ was collected from each participant into a heparinised tube at inclusion. The participants did not fast at the time of the blood sampling. Collection and fractionation blood samples into serum and buffy coat, and storage at $-80{ }^{\circ} \mathrm{C}$ followed the standardised routines before measurement. Serum CCL11/Eotaxin-1 concentration was measured in serum samples using a sandwich enzyme immunoassay manufactured (R\&D Systems, Minneapolis, MN, USA). The absorbance was measured at $450 \mathrm{~nm}$. Data were expressed as $\mathrm{pg} / \mathrm{mL}$. The sensitivity of the assay is less than 5 $\mathrm{pg} / \mathrm{mL}$. We also investigated inflammation markers IL-6 (R\&D Systems, Minneapolis, MN, USA), as well as serum markers of bone remodelling, C-telopeptide cross-linked collagen type 1 (CTX-1) (R\&D Systems, Minneapolis, MN, USA). All assays had an intra-and inter-variability lower than $10 \%$. Each sample was repeated for three times and the value obtained represents the mean of three results.

\section{BMD measurement}

The BMD values (Unit: $\mathrm{g} / \mathrm{cm}^{2}$ ) of the lumbar spine (L1-4), femoral neck and total hip were determined by Dual-energy X-ray absorptiometry
(DXA, Hologic QDR-2000, Hologic Corporation, Waltham, MA, USA), and the CVs for the DXA measurements at L1-4, the total hip, and the femoral neck were $1.30 \%, 0.93 \%$, and $2.17 \%$, respectively.

\section{Definition of clinical severity}

The Visual Analogue Scale (VAS) and Oswestry Disability Index (ODI) scores were recorded to evaluate the clinical severity in POMP females. The VAS is a $10 \mathrm{~cm}$ long straight line, marked at each end with labels which anchor the scale. Patients are asked to place a mark on the line at a point representing the severity of their pain where $0 \mathrm{~cm}$ indicates "no pain « and $10 \mathrm{~cm}$ represents "pain as bad as it could be (17). The ODI consists of 10 items on the degree of severity to which back (or leg) trouble has affected the ability to manage in everyday life (18). The 10 sections cover the pain and daily function (including pain intensity, personal hygiene, lifting, walking, sitting, standing, sleeping, sexual activity, social activity, and travelling). Each item is rated on a 6point scale (0-5); the higher the score indicates, the higher the level of disability.

\section{Statistical analysis}

Statistical analysis of the data was performed using Graph Pad 6.0 software. Kolmogorov-Smirnov tests were employed to assess a normal distribution of the variables. Normally distributed measurement data were presented as mean $\pm S D$. The difference was compared with one-way analysis of variance (One-way ANOVA) The Tamhane or Tukey test was applied for post-hoc analysis. Pearson correlation coefficient was calculated to describe the correlations between CCL11 and various variables, where appropriate. Multivariate linear regression analysis was performed to determine further whether CCL11 could serve as an independent marker. A $P$-value of less than 0.05 was considered significant. Statistic power (1- $\beta$ ) was calculated by using software PASS (Power Analysis and Sample Size) 2008 Statistical Software (UT, USA), using the formula below according to the obtained data of different mean CCL11 levels, standard error, enrolled numbers of patients in each group (19). Statistical power was regarded strong when $>0.8$. The detailed calculation formula is listed below:

$$
1-\beta=\varphi\left(z-z_{1-\alpha / 2}\right)+\varphi\left(-z-z_{1-\alpha / 2}\right), z=\sigma\left(\mu_{A}-\mu_{B}\right) / \sigma\left(\frac{1}{n_{A}}+\frac{1}{n_{B}}\right)
$$

\section{Results}

\section{Demographic statistics of enrolled participants}

The clinical characteristics of the study samples are summarized in Table $I$. The mean value of age was $54.6 \pm 0.8$, and body mass index (BMI) was $24.2 \pm 0.2 \mathrm{~kg} / \mathrm{m}^{2}$ with mean postmenopausal $3.6 \pm$ 0.8 years in PMOP group, suggesting the enrolled 
Table I Demographic statistics of enrolled participants.

\begin{tabular}{|l|c|c|c|c|}
\hline & PMOP $(\mathrm{n}=83)$ & PMNOP $(\mathrm{n}=82)$ & Control $(\mathrm{n}=85)$ & $P$ value \\
\hline Age & $54.6 \pm 0.8 * *$ & $54.5 \pm 1.1^{* *}$ & $42.3 \pm 3.7$ & 0.023 \\
\hline Years of menopause & $3.6 \pm 0.8$ & $3.5 \pm 0.9$ & - & 0.818 \\
\hline BMI $\left(\mathrm{kg} / \mathrm{m}^{2}\right)$ & $24.2 \pm 0.2$ & $23.9 \pm 0.3$ & $24.0 \pm 0.3$ & 0.095 \\
\hline $\mathrm{CCL} 11(\mathrm{pg} / \mathrm{mL})$ & $170.2 \pm 21.0 * \#$ & $127.5 \pm 11.2$ & $125.1 \pm 11.3$ & $<0.001$ \\
\hline
\end{tabular}

Data are conveyed as the mean value $\pm S D$. ${ }^{*} P<0.01$ in comparison with control, ${ }^{*} P<0.05$ in comparison with control, $\# P<0.05$, in comparison with the PMNOP group.

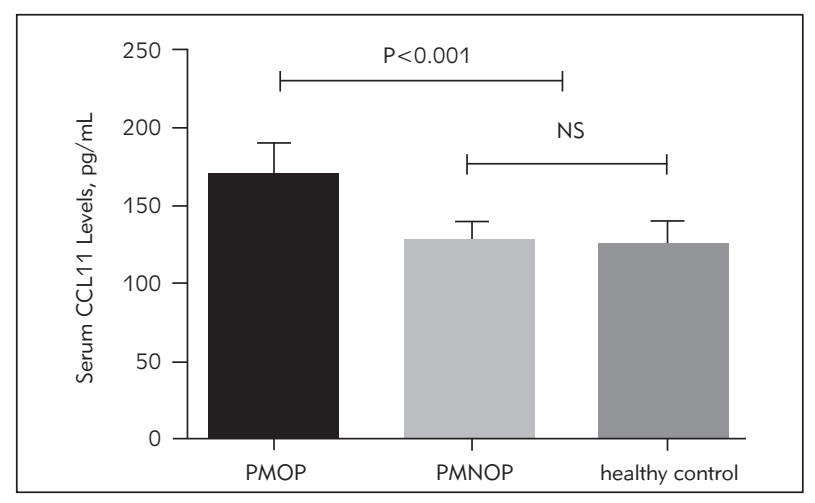

Figure 1 Comparison of serum CCL11 levels among PMOP, PMNOP and healthy controls.
Table II Comparisons of the BMD at the femoral neck, total hip, and L1-L4 lumbar spine among the PMOP, PMNOP and healthy control groups. (Unit: $\mathrm{g} / \mathrm{cm}^{2}$ ).

\begin{tabular}{|l|c|c|c|}
\hline & $\begin{array}{c}\text { Control } \\
(\mathrm{n}=85)\end{array}$ & $\begin{array}{c}\text { PMNOP } \\
(\mathrm{n}=83)\end{array}$ & $\begin{array}{c}\text { PMOP } \\
(\mathrm{n}=83)\end{array}$ \\
\hline BMD (Neck) & $1.04 \pm 0.14$ & $0.94 \pm 0.11^{*}$ & $0.87 \pm 0.09 * * \#$ \\
\hline BMD (Hip) & $1.13 \pm 0.15$ & $0.98 \pm 0.13^{*}$ & $0.79 \pm 0.11 * * \#$ \\
\hline BMD (L1-4) & $1.22 \pm 0.20$ & $0.86 \pm 0.12 *$ & $0.74 \pm 0.13^{* *} \#$ \\
\hline
\end{tabular}

All data were presented as mean \pm standard deviation. ${ }^{*} \mathrm{P}<0.05$, compared with the healthy control group; $* * P<0.01$, compared with the control group; \#P $<0.05$, compared with the PMNOP group.
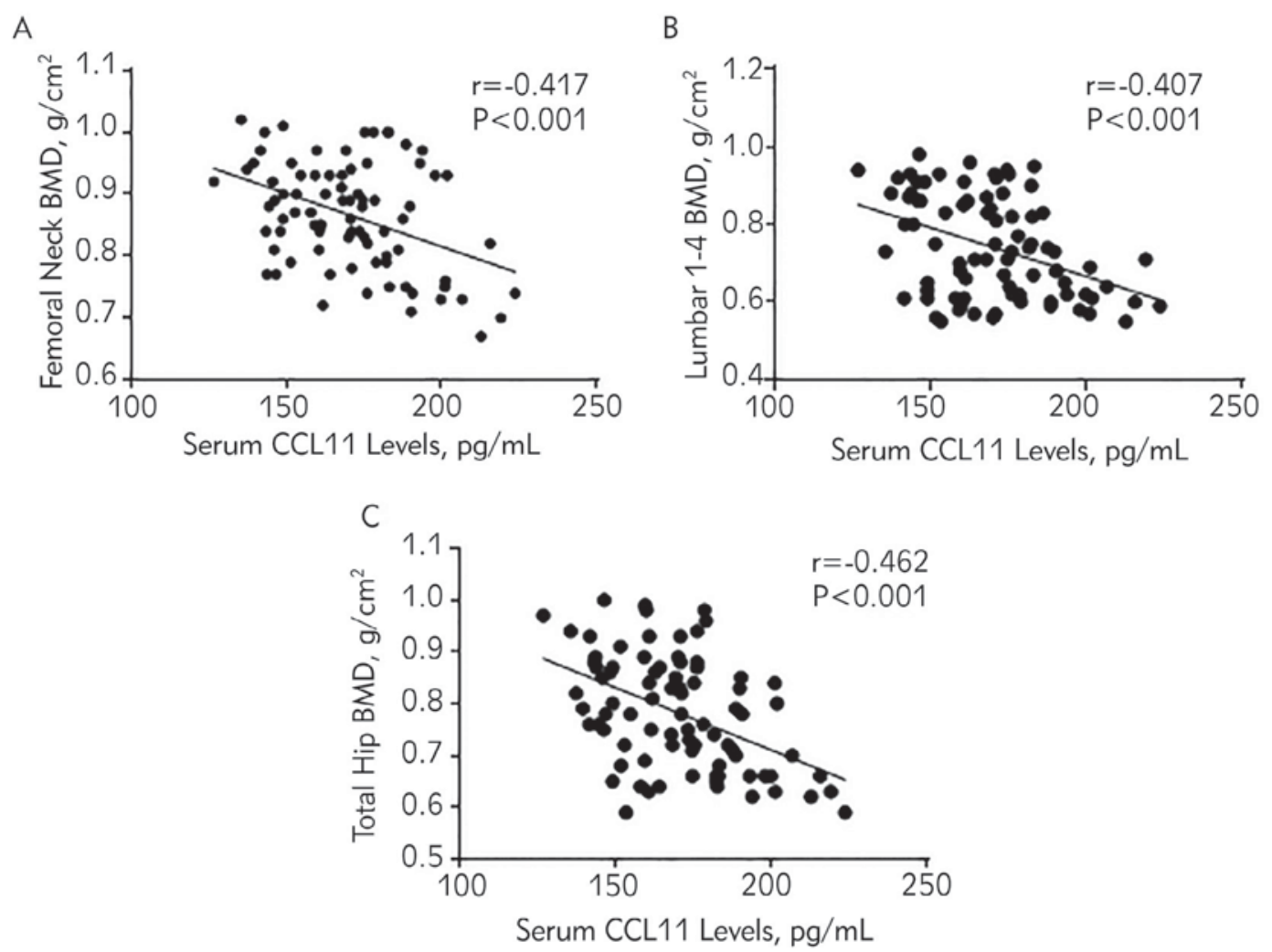

Figure 2 Correlation of serum CCL11 levels with BMDs (A). Correlation of serum CCL11 levels with femoral neck BMD (B). Correlation of serum CCL11 levels with lumbar 1-4 BMD (C). Correlation of serum CCL11 levels with total hip BMD. 
subjects were slightly overweight. The average age was $54.5 \pm 1.1$ years with mean postmenopausal 3.5 \pm 0.9 years in PMNOP group and mean age $42.3 \pm 3.7$ years in the control group. No significant differences of $\mathrm{BMI}$ were noted among the three groups. Participants in PMOP and PMNOP groups were significantly older than in control one. Serum CCL11 concentrations were significantly higher in the PMOP group than in the PMNOP group $(170.2 \pm 21.0 \mathrm{pg} / \mathrm{mL}$ vs $127.5 \pm 11.2$ $\mathrm{pg} / \mathrm{mL}, P<0.001)$ and the control group (170.2 \pm 21.0 $\mathrm{pg} / \mathrm{mL}$ vs $125.1 \pm 11.3 \mathrm{pg} / \mathrm{mL}, P<0.001$ ) (Figure 1, Table I). However, the serum CCL11 levels were not statistically significant between PMNOP and healthy control group (127.5 $\pm 11.2 \mathrm{pg} / \mathrm{mL}$ vs $125.1 \pm 11.3$ $\mathrm{pg} / \mathrm{mL}, P>0.05)$ The statistical power was 0.85 after calculation.

Correlation analysis between serum CCL11 levels and BMDs

To further investigate the effect of CCL11 on $B M D$, we investigated the correlation of serum CCL11 levels and BMD. According to Spearman correlation analysis, CCL11 showed a significant negative association with $B M D s$ at the femoral neck $(r=-0.417, P<0.001)$ (Figure $2 A)$, lumbar spine 1-4 $(r=-0.407, P<0.001)$ (Figure $2 B)$ and total hip $(r=$ $-0.462, \mathrm{P}<0.001$ ) (Figure $2 \mathrm{C}$ ). These correlations remained significant after adjusted by age and $\mathrm{BMI}$ (femoral neck: $\mathrm{R}=-0.343, P<0.001$; lumbar spine 14: $\mathrm{R}=-0.333, P=0.002$; total hip: $\mathrm{R}=-0.392$, $P<0.001$ ) (Table III).

\section{Correlation analysis between serum CCL11} levels and clinical severity

To further investigate whether CCL11 is associated with symptomatic severity, we explored the relationships between serum CCL11 levels between VAS as well as ODI scores. Accordingly, we observed that serum CCL11 levels were positively related to symptomatic severity determined by VAS $(r=0.352$, $P=0.001)$ (Figure $3 A$ ) and ODI $(r=0.346, P=0.001)$ (Figure 3B). These correlations remain significant after adjusted by age and BMI (VAS: $R=0.283$, $P=0.031$; ODI: $R=0.275, P=0.034$ ) (Table III).

Table III Correlation of serum CCL11 concentrations with BMDs, clinical severity and biochemical indices in PMOP females following adjusted by age and BMI.

\begin{tabular}{|l|c|c|c|c|}
\hline & \multicolumn{2}{|c|}{$\begin{array}{c}\text { Serum CCL11 } \\
\text { concentration } \\
(\mathrm{pg} / \mathrm{mL})\end{array}$} & \multicolumn{2}{c|}{$\begin{array}{c}\text { Serum CCL11 } \\
\text { concentration } \\
(\mathrm{pg} / \mathrm{mL})\end{array}$} \\
\hline Variables & $r$ & $P$ & $R$ & $P$ \\
\hline BMI & 0.113 & 0.085 & - & - \\
\hline Age & 0.078 & 0.144 & - & - \\
\hline $\begin{array}{l}\text { Femoral Neck } \\
\text { BMD }\end{array}$ & -0.417 & $<0.001$ & -0.343 & $<0.001$ \\
\hline Total hip BMD & -0.462 & $<0.001$ & -0.392 & $<0.001$ \\
\hline $\begin{array}{l}\text { Lumbar spine 1-4 } \\
\text { BMD }\end{array}$ & -0.407 & $<0.001$ & -0.333 & 0.002 \\
\hline VAS & 0.352 & 0.001 & 0.283 & 0.031 \\
\hline ODI & 0.346 & 0.001 & 0.275 & 0.034 \\
\hline $\begin{array}{l}\text { Serum CTX-1 } \\
\text { Levels }\end{array}$ & 0.450 & $<0.001$ & 0.381 & $<0.001$ \\
\hline Serum IL-6 Levels & 0.326 & 0.003 & 0.252 & 0.042 \\
\hline
\end{tabular}

*Adjusted by age and BMI.
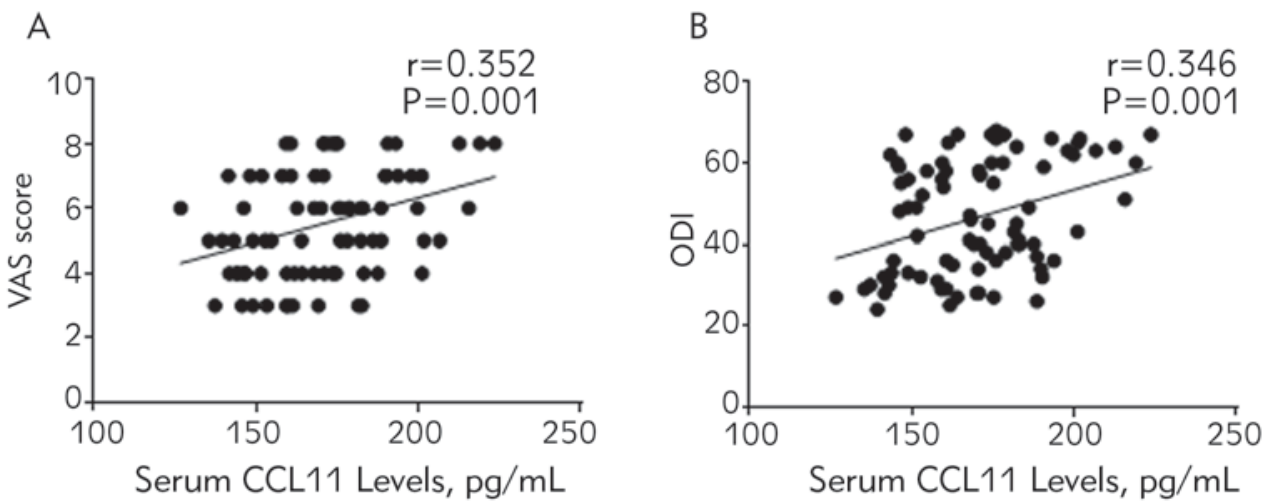

Figure 3 Correlation of serum CCL11 levels with clinical severity (A). Correlation of serum CCL11 levels with VAS scores (B). Correlation of serum CCL11 levels with ODI index. 

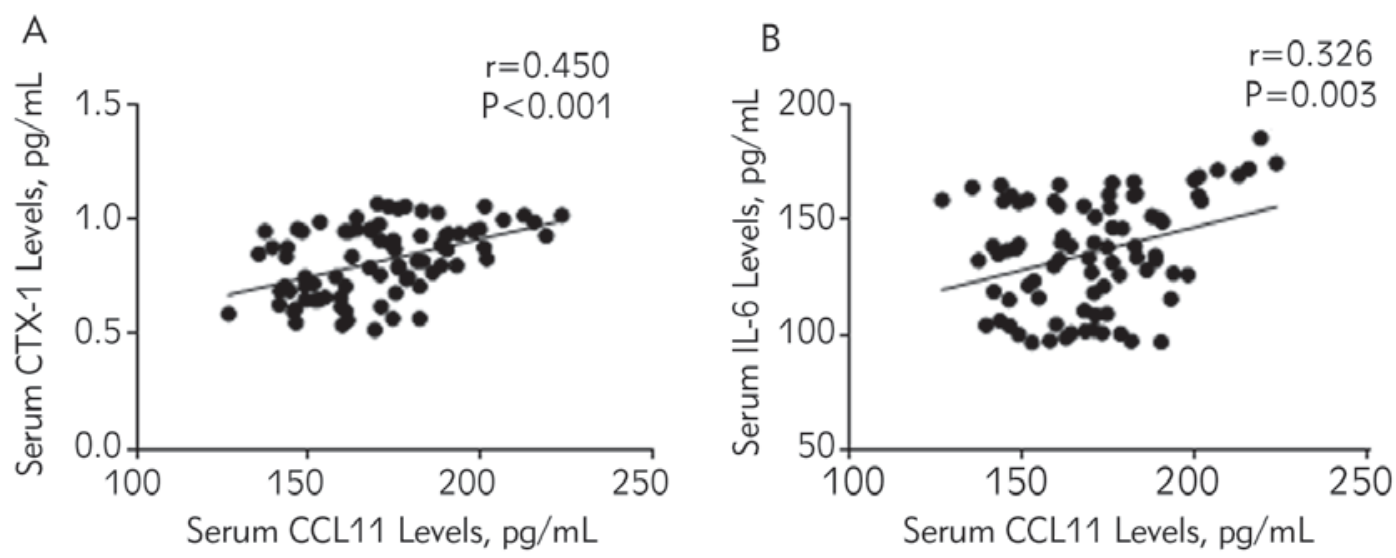

Figure 4 Correlation of serum CCL11 levels with biochemical indices (A). Correlation of serum CCL11 levels with serum CTX-1 levels (B). Correlation of serum CCL11 levels with serum IL-6 levels.

Table IV Multivariate linear regression.

\begin{tabular}{|l|c|c|c|c|c|c|c|c|c|c|}
\hline & \multicolumn{2}{|c|}{$\begin{array}{c}\text { Femoral Neck } \\
\text { BMD }\end{array}$} & \multicolumn{2}{c|}{$\begin{array}{c}\text { Total hip } \\
\text { BMD }\end{array}$} & \multicolumn{2}{c|}{$\begin{array}{c}\text { Lumbar spine 1-4 } \\
\text { BMD }\end{array}$} & \multicolumn{2}{c|}{ Serum CTX-1 } & \multicolumn{2}{c|}{ Serum IL-6 } \\
\cline { 2 - 11 } & $\beta$ & $P$ & $\beta$ & $P$ & $\beta$ & $P$ & $\beta$ & $P$ & $\beta$ & $P$ \\
\hline Age & -0.066 & 0.375 & -0.052 & 0.599 & -0.048 & 0.611 & -0.066 & 0.865 & -0.058 & 0.911 \\
\hline BMI & 0.142 & 0.118 & 0.123 & 0.125 & 0.114 & 0.111 & 0.159 & 0.092 & 0.164 & 0.090 \\
\hline $\begin{array}{l}\text { Serum } \\
\text { CCL11 }\end{array}$ & -1.322 & 0.002 & -1.536 & 0.001 & -1.375 & 0.002 & 1.503 & 0.001 & 0.984 & 0.047 \\
\hline
\end{tabular}

Correlation analysis between serum CCL11 levels and biochemical indices

We finally examined the correlation of serum CCL11 concentrations with biochemical indices including the bone resorption factor CTX-1 and inflammation biomarker IL-6. We also demonstrated CCL11 was positively related to CTX-1 $(r=0.450$, $P<0.001)$ and IL-6 $(r=0.326, P=0.003)$. These correlations remain significant after adjusted by age and BMI (CTX-1: $R=0.381, P<0.00 ; \quad I L-6: R=0.252$, $P=0.042)$ (Table III).

\section{Discussion}

The main findings of this study demonstrate that serum levels of CCL11/Eotaxin-1 are increased in PMOP patients, compared with PMNOP and healthy controls. Moreover, we observed a negative correlation of CCL11/Eotaxin-1 concentration with BMD and positive associations with clinical severity and biochemical indices. These correlations still remain significant after adjusting for age and BMI. Further multivariate linear regression analysis demonstrated that CCL11/Eotaxin-1 could serve as an independent marker. Our findings implicate that serum CCL11/ Eotaxin-1 may serve as a potential biomarker for PMOP progression.

Over the past years, studies have elucidated, in addition to the endocrine aspect, unanticipated connections between the immune and skeletal systems, and this relationship has led to the development of a new field known as "osteoimmunology" (20). A series of works have identified that dysregulation of the immune system was related to the initiation of different inflammatory autoimmune diseases contributing to adverse effects on bone integrity (21). In addition, the immune system impacts and regulates bone remodelling in physiological and pathological conditions through the immune-skeletal interface, have led to a new concept of OP as a sort of chronic immune-mediated disease $(22,23)$. During menopause, estrogen levels fall, whereas pro-inflammatory factors and macrophage levels increase, all of which accelerate the bone remodelling cycle, with consequent activation of osteoclasts and greater bone resorption $(24,25)$.

Chemokines are some of the most important cytokines during the autoimmune and inflammatory 
process. In recent studies, chemokines have been observed to be correlated with pathological bone loss in this disease, including osteoporosis, rheumatoid arthritis and multiple myeloma (26). In our study, we first showed that serum CCL11 levels were negatively correlated with the BMDs at the femoral neck, lumbar spine 1-4 and total hip, indicating CCL11 in osteoclasts migration may play important roles in BMD reduction.

Next, we also found that serum CCL11 levels are strongly related to the clinical severity defined by VAS and ODI, implicating that CCL11 may be involved in the process inflammatory and neuropathic pain in OP. The two scales including VAS and ODI are most frequently used measurements of low back pain and functional ability in OP patients, and the psychometric properties of both the VAS and ODI have been shown to be valid and reliable in OP patients (27, 28). Bone pain is the most common complaint in OP patients leading to impaired quality of life. Studies have identified that both peripheral and central components participate in the bone pain in OP patients (29). In elderly OP patients, there has been an increased density of bone sensory nerve fibres along with enhanced expressions of nociceptors sensitised by the lowering $\mathrm{pH}$ result from the osteoclastic activity (29). Meanwhile, during the OP process, the bone sensory nerve fibres may undergo pathological modifications (30). The role of CCL11 in pain production and maintenance has been investigated before. Previous studies have identified that CCL11 was involved in many pathological processes of painrelated diseases. Gul E et al. (31) found that CCL11 levels were significantly higher in patients with primary dysmenorrhea than the control subjects. In another study, single nucleotide polymorphisms (SNPs) of gene CCL11 served as a marker for the disease of fibromyalgia, a chronic pain syndrome (32). In addition, higher levels of CCL11 were found in neuropathic pain cohorts compared with healthy controls, pointing to the role of CCL11 in neuroinflammation (33).

Last, we discovered that serum CCL11 levels were positively associated with the CTX-1 and IL-6 levels in PMOP patients. CTX-1 has been reported to

\section{References}

1. Alejandro P, Constantinescu F. A Review of Osteoporosis in the Older Adult: An Update. Rheum Dis Clin North Am 2018; 44: 437-51.

2. Rachner TD, Khosla S, Hofbauer LC. Osteoporosis: now and the future. Lancet 2011; 377: 1276-87.

3. Eastell R, O’Neill TW, Hofbauer LC, et al. Postmenopausal osteoporosis. Nat Rev Dis Primers 2016; 2: 16069. be a sensitive biochemical marker of bone turnover (34), and the serum CTX-1 could reflect the increase of bone resorption in OP patients with vertebral fractures and hip fractures (35). IL-6 has been identified as an important cytokine in the process of bone resorption through suppressing osteoblast function while upregulating osteoclasts in the presence of RANKL $(36,37)$. These findings implicated that CCL11 was elevated along with bone resorption factors and inflammatory markers through certain and unknown mechanisms which remain to be explored.

In this study, we should be aware of several potential limitations. First, our study was based on a small sample size of enrolled patients. A further study conducted on a random sample of a larger population will be needed to substantiate our results. Secondly, only CCL11/Eotaxin-1 levels were examined in serum. Additional immune-histochemical investigations of CCL11/Eotaxin-1 and its receptor CC3R expression in bone tissue could provide further valuable information on the pathogenic role of CCL11/CC3R in osteoporosis. Last, we did not investigate other chemokines which have been proposed to be associated with osteoclasts activity.

Collectively, this study has revealed a significant elevation in serum CCL11/Eotaxin-1 of OP patients and illustrated a pronounced positive association with the extent of disease severity in patients with PMOP. The data of this study support the finding that CCL11/Eotaxin-1 may serve as a useful prognostic parameter to reflect the disease severity PMOP. This study has been the first to investigate such a correlation, and further studies will be required to define the mechanisms underlying this association. Additional investigations will be required to shed light on the possible role of CCL11/Eotaxin-1 involved in the pathogenesis of PMOP, with the aim of developing effective pharmacological agents to delay the progression of osteoporosis.

\section{Conflict of interest statement}

The authors declare that they have no conflicts of interest.
4. Kanis JA, Johnell O, Oden A, et al. Risk of hip fracture according to the World Health Organization criteria for osteopenia and osteoporosis. Bone 2000; 27: 585-90.

5. Bainbridge KE, Sowers MF, Crutchfield M, et al. Natural history of bone loss over 6 years among premenopausal and early postmenopausal women. Am J Epidemiol 2002; 156: 410-7. 
6. Kanis JA, McCloskey EV, Johansson $\mathrm{H}$, et al. European guidance for the diagnosis and management of osteoporosis in postmenopausal women. Osteoporos Int 2013; 24: 23-57.

7. Link TM. Radiology of Osteoporosis. Can Assoc Radiol J 2016; 67: 28-40.

8. Garnero P. The Utility of Biomarkers in Osteoporosis Management. Mol Diagn Ther 2017; 21: 401-18.

9. Baggiolini M, Dewald B, MoSeries B. Human chemokines: An update. Annu Rev Immunol 1997; 15: 675705 .

10. Legler DF, Thelen M. Chemokines: Chemistry, Biochemistry and Biological Function. Chimia (Aarau). 2016; 70: 856-9.

11. Miller MC, Mayo KH. Chemokines from a Structural Perspective. Int J Mol Sci 2017; 18: pii: E2088.

12. Van Coillie E, Van Damme J, Opdenakker G: The MCP/eotaxin subfamily of CC chemokines. Cytokine Growth Factor Rev 1999; 10: 61-86.

13. Williams TJ. Eotaxin-1 (CCL11). Front Immunol 2015; 24: 84.

14. Liu YZ, Dvornyk $V$, Lu $Y$, et al.: A novel pathophysiological mechanism for osteoporosis suggested by an in vivo gene expression study of circulating monocytes. J Biol Chem 2005; 280: 29011-6.

15. Kindstedt E, Holm CK, Sulniute R, et al. CCL11, a novel mediator of inflammatory bone resorption. Sci Rep 2017; 7: 5334.

16. Syversen SW, Goll GL, Haavardsholm EA, et al. A high serum level of eotaxin (CCL 11) is associated with less radiographic progression in early rheumatoid arthritis patients. Arthritis Res Ther 2008; 10: R28.

17. Bird SB, Dickson EW. Clinically significant changes in pain along the visual analogue scale. Ann Emerg Med 2001; 38: 639-43.

18. Fairbank JC, Pynsent PB. The Oswestry Disability Index. Spine 2000; 25: 2940-53.

19. Chow S, Shao J, Wang H. Sample Size Calculations in Clinical Research. 2nd Ed.2008 Chapman \& Hall/CRC Biostatistics Series. page 58.

20. Mensah KA, Li J, Schwarz EM. The emerging field of osteoimmunology. Immunol Res 2009; 45: 100-13.

21. Mclnnes IB, Schett G. Cytokines in the pathogenesis of rheumatoid arthritis. Nat Rev Immunol 2007; 7: 429-42.

22. Rauner M, Sipos W, Thiele S, Pietschmann P. Advances in osteoimmunology: pathophysiologic concepts and treatment opportunities. Int Arch Allergy Immunol 2013; 160: 114-25. doi: 10.1159/000342426.

23. Charles JF, Nakamura MC. Bone and the innate immune system. Curr Osteoporos Rep 2014; 12: 1-8. doi: 10.1007/s11914-014-0195-2.
24. Pacifici R. Estrogen, cytokines and pathogenesis of postmenopausal osteoporosis. J Bone Miner Res 1996; 11: 1043-51.

25. Genco RJ, Grossi SG. Is estrogen deficiency a risk factor for periodontal disease? Compend Contin Educ Dent Suppl 1998; 22: S23-S29.

26. Galliera E, Locati M, Mantovani A, et al. Chemokines and bone remodelling. Int J Immunopathol Pharmacol 2008; 21: 485-91.

27. Imai T, Tanaka S, Kawakami K, et al. Health state utility values and patient-reported outcomes before and after vertebral and non-vertebral fractures in an osteoporosis clinical trial. Osteoporos Int 2017; 28: 1893-901.

28. Hu Z, Man GCW, Kwok AKL, et al. Global sagittal alignment in elderly patients with osteoporosis and its relationship with severity of vertebral fracture and quality of life. Arch Osteoporos 2018; 13: 95.

29. Jimenez-Andrade JM, Mantyh WG, Bloom AP, et al. The effect of aging on the density of the sensory nerve fiber innervation of bone and acute skeletal pain. Neurobiol Aging 2010; 33: 921-32.

30. Mattia C, Coluzzi F, Celidonio L, et al. Bone pain mechanism in osteoporosis: a narrative review. Clin Cases Miner Bone Metab 2016; 13: 97-100.

31. Gul E, Celik Kavak E. Eotaxin levels in patients with primary dysmenorrhea J Pain Res 2018; 11: 611-3.

32. Zhang Z, Feng J, Mao A, et al. SNPs in inflammatory genes CCL11, CCL4 and MEFV in a fibromyalgia family study. PLoS One 2018 Jun 21; 13: e0198625.

33. Bäckryd $E$, Lind $A L$, Thulin $M$, et al. High levels of cerebrospinal fluid chemokines point to the presence of neuroinflammation in peripheral neuropathic pain: a cross-sectional study of 2 cohorts of patients compared with healthy controls. Pain 2017; 158: 2487-95.

34. Rosen HN, Moses AC, Garber J, et al. Serum CTX: A new marker of bone resorption that shows treatment effect more often than other markers because of low coefficient of variability and large changes with bisphosphonate therapy. Calcified Tissue International 2000; 66: 100-3.

35. Kawana K, Takahashi M, Hoshino H, et al. Comparison of serum and urinary C-terminal telopeptide of type I collagen in aging, menopause and osteoporosis. Clin Chim Acta 2002; 316: 109-15.

36. Abdel Meguid MH, Hamad YH, Swilam RS, et al. Relation of interleukin- 6 in rheumatoid arthritis patients to systemic bone loss and structural bone damage. Rheumatol Int 2013; 33: 697-703.

37. Iseme RA, Mcevoy M, Kelly B, et al. Is osteoporosis an autoimmune mediated disorder? Bone Rep 2017; 7: $121-31$. 